\title{
The Characteristics of Synbiotic Yoghurt Freeze- Drying Supplemented by Purple Sweet Potato (Study on Sucrose Concentration as Cryoprotectant)
}

\author{
Agustina Intan Niken Tari \\ Universitas Veteran Bangun Nusantara \\ Sukoharjo, Indonesia \\ intanniken@gmail.com
}

\author{
Catur Budi Handayani \\ Universitas Veteran Bangun Nusantara \\ Sukoharjo, Indonesia \\ caturjazuli@yahoo.com
}

\author{
Sri Hartati \\ Universitas Veteran Bangun Nusantara \\ Sukoharjo, Indoenesia \\ srihartati@univetbantara.ac.id
}

\begin{abstract}
Synbiotic yogurt with purple sweet potatoes as prebiotics and Lactobacillus plantarum Dad 13 isolated from Dadih as probiotic has potential as a functional food, but it requires at low storage temperatures. Freeze-drying technique requires cryoprotectant as a protective product such as yogurt. The aims of this research were to determine the proper sucrose concentration as cryoprotectant to obtain a high level of total of Lactic Acid Bacteria and good chemical properties. This research was conducted in a completely randomized design with one factor ie sucrose concentration : $0 \%, 2,5 \%, 5 \%$, $7,5 \%$, and was carried out in three replicates. The result showed that sucrose concentration significantly affected the levels of reducing sugar, total plate counts (TPC) of Lactic Acid Bacteria (LAB) after freeze-drying, but had no effect on the water content and TPC of LAB before freeze-drying. The best treatment, resulted in sucrose $5 \%$ as cryoprotectant, had the following characteristic, water content of $7,51 \%$, reducing sugar of $14,59 \%$, TPC of LAB level of $1,98 \times 10^{9} \mathrm{CFU} / \mathrm{g}$, before freeze-drying, and TPC of LAB level of $9,28 \times 10^{8}$ CFU/g after freeze-drying.
\end{abstract}

Keywords - cryoprotectant, freeze drying, synbiotic, yogurt.

\section{INTRODUCTION}

Important factors in supporting the health of the body, among others, is determined by bacteria in the gastrointestinal tract. Therefore the balance of bacterial populations in the gastrointestinal tract must be maintained. One of the efforts made was by consuming synbiotic yogurt. One type of synbiotic yogurt is local probiotic based yogurt and purple sweet potato extract supplementation.

[1] reported that yogurt with purple sweet potato extract supplementation using commercial culture and indigenous probiotics, namely Streptococcus thermophillus FNCC 0040, Lactobacillus bulgaricus FNCC0041 and Lactobacillus plantarum Dad 13 with a ratio of 1: 1: 0.5 can be made . and has physical properties $(\mathrm{pH}=3.78$, viscosity $=5.1987 \mathrm{cP}$, chromatic color $=18.559)$, chemical properties (titrated acid content $1.2733 \%$, water content $85.2664 \%$, ash content $0.8041 \%$, levels $3.3278 \%$ reduction sugar, $1.4782 \%$ dissolved protein content, $0.08 \%$ fat content and $8.5315 \%$ anthocyanin content.

According to [2] fermented milk products must be stored at temperatures less than $10 \mathrm{oC}$ to avoid the negative effects of the environment. This low temperatures storage is needed to inhibit the fermentation process so that the number of microbes remains high. This causes high storage and distribution costs. One overcome this obstacle is by making instant fermented drinks. Frozen drying techniques are commonly used for products that have low heat resistance. The presence of freeze drying with very low temperatures ($40^{\circ} \mathrm{C}$ ) can affect microbial viability. According to [3] the freeze drying process can reduce the number of bacteria to 1 $\log$ cycle. In addition, the freezing process allows death or sublethal microbes, so it is necessary to add protective substances (cryoprotectant) during microbial growth or before freezing or freeze-dried processes to minimize damage.

According to [4] sucrose is known as a bacterial protective ingredient that is safe for consumption and can improve sweetness. The ability of sucrose as a cryoprotectant is to protect the structure and function of proteins in microbial cells [5]

The ability of sucrose as a cryoprotectant agent in lactic fermentation drinks is known as indigenous (local) probiotic yogurt with sweet potato supplementation with freezedrying techniques on water content, solubility and total viability of Lactic Acid Bacteria (LAB). That is why this research needs to be done. The purpose of this study was to study the water content, reducing sugar content and viability of BAL in freeze-dried lactate fermentation drinks

\section{MATERIAL AND METHODS}

The material used consisted of lactic acid bacteria collection of FNCC (Food and Nutrition Culture Collection) from UGM Food and Nutrition PAU Yogyakarta shaped upright, namely Streptococcus thermophillus FNCC 0040, Lactobacillus bulgaricus FNCC 0041, a culture of probiotic indigenous LAB Lactobacillus plantarum Dad 13.

The MRS media (de Mann Rogossa Sharp) Agar / Broth (Oxoid), is used for the maintenance of Lactic Acid Bacteria Cultures. LPS media is a selective medium for the growth of Lactobacillus plantarum Dad 13. Supporting chemicals such as $70 \%$ alcohol, spirits, and distilled water are obtained from the Lab. Biology-Chemistry and Microbiology Faculty of Agriculture Univet Bantara Sukoharjo. The equipment used includes glassware (test tubes, Beaker, Erlenmeyer, and petridish), autoclave (All America), incubators (Inko), Ovens (Binders), entcas.

The stages of this study include making a culture stock, making starter culture, making purple sweet potato extract, making probiotic yogurt with supplementation of purple sweet potato extract and freeze drying. 


\section{A. Flowchart of implementation}

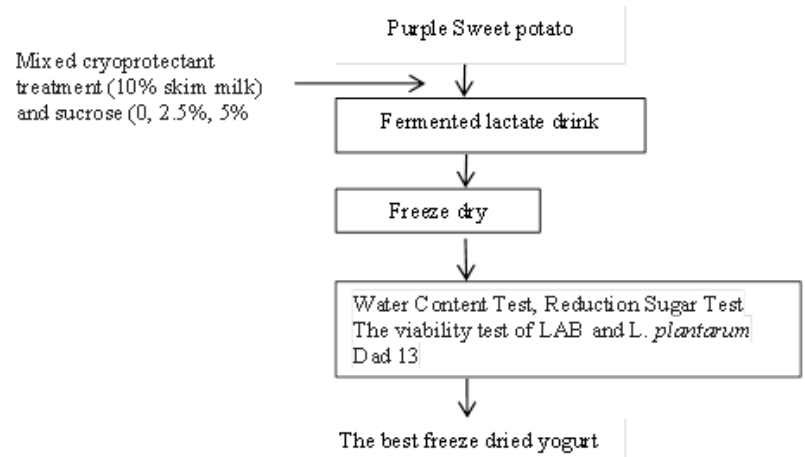

Figure 1. Research flow chart

This study used a completely randomized design of one treatment, namely cryoprotectant concentration in the form of $10 \%$ skim milk mixture and sucrose (S), with different concentrations, namely $\mathrm{S} 1=0 \%, \mathrm{~S} 2=2.5 \%, \mathrm{~S} 3=5 \%$ and $\mathrm{S} 4=7,5 \%$. The study carried out 3 replications so that 12 units of experiment were obtained. The observed parameters were the total viability of Lactic Acid Bacteria (LAB) before and after freeze dried, moisture content, solubility and reducing sugar content. The data obtained in the study were analyzed using RCD-one way Anova. If the treatment shows a real influence, then it is continued with the DMRT test [6]

\section{RESULTS AND DISCUSSION}

\section{A. Water Content}

The water content of the final product is an important parameter in making instant products. The use of sucrose as cryoprotectant has no effect on the water content of the synbiotic product as shown in Figure 2. This is possible because the interval of sucrose concentration used as a cryoprotectant is small, so it does not give enough influence on the moisture content of the product. Nevertheless, [7] argued that, the use of sucrose is cryoprotective and can be used as a drying medium because it can form porous structures that can facilitate the removal of water in the product during freeze- drying and facilitate the rehydration process in the product during freeze- drying and facilitate the rehydration process

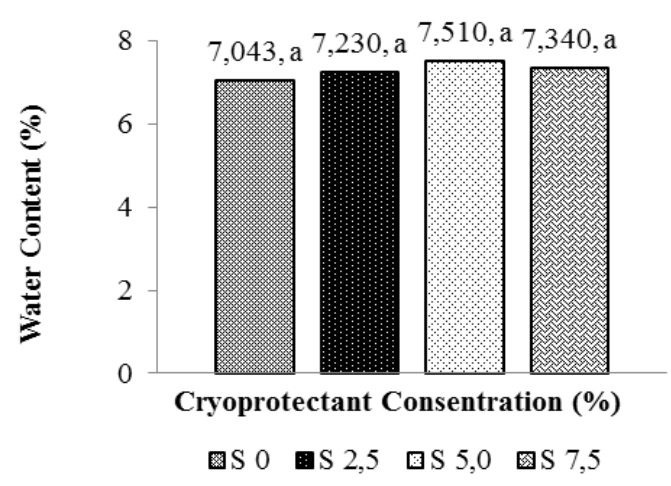

Figure 2. Effect of sucrose on yogurt water content of synbiotic supplementation of purple sweet potato extract

\section{B. Reduction Sugar Levels}

Reduction sugar is a group of monosaccharides and disaccharides which have free reduction groups, such as glucose, fructose, lactose, galactose and maltose (Girindra, 1993). [8]. Figure 3 shows that the concentration of sucrose as cryoprotectant had a significantly different effect ( $p>$ $0.05)$ on

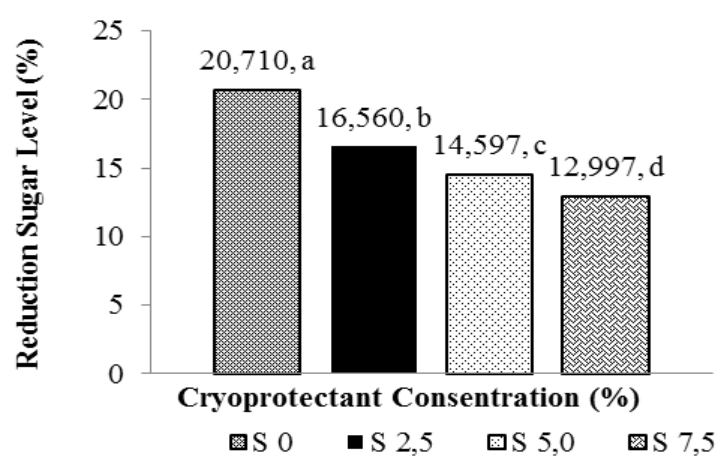

Figure 3 Effect of sucrose on yogurt reducing sugar content of synbiotic supplementation of purple sweet potato extract

The decrease in reducing sugar levels is thought to be due to the use of reducing sugars as an energy source for growth and cell multiplication and the formation of metabolites by bacteria. This is consistent with the statement of [9] which states that lactic acid bacteria use sugar as an energy source for growth and produce lactic acid during the fermentation process

\section{Total Lactic Acid Bacteria (LAB)}

Total LAB measurement is an important parameter, which is closely related to the use of sucrose as a cryoprotectant. [10] states that good protection in the freezedrying process must be cryoprotective, easy to dry and able to form a good matrix to maintain cell stability, and is easily rehydrated. Sucrose is a cryoprotectant that meets these criteria. The effect of sucrose as a cryoprotectant concentration can be seen in Table 1 .

Table 1. Average total LAB of synbiotic yogurt before and after freeze drying

\begin{tabular}{c|c|c}
\hline $\begin{array}{c}\text { Sucrosa } \\
\text { Consentration } \\
(\%)\end{array}$ & \multicolumn{2}{|c}{ Average total LAB (8 log CFU/ml) } \\
\cline { 2 - 3 } & $\begin{array}{c}\text { Before Freeze } \\
\text { drying }\end{array}$ & $\begin{array}{c}\text { After Freeze } \\
\text { drying }\end{array}$ \\
\hline 0 & $39,77 \mathrm{a}$ & $2,90 \mathrm{a}$ \\
2,5 & $21,80 \mathrm{a}$ & $2,75 \mathrm{a}$ \\
5,0 & $12,93 \mathrm{a}$ & $9,28 \mathrm{~b}$ \\
7,5 & $21,47 \mathrm{a}$ & $3,42 \mathrm{a}$ \\
\hline
\end{tabular}

Note: Numbers that have the same letter notation mean that they are not significantly different in the DMRT test $\alpha=0.05$

Table 1 shows that the average total LAB before freeze drying was between $12.93 \times 108-39.77 \times 10^{8} \mathrm{CFU} / \mathrm{ml}$ or in the range of $10^{9} \mathrm{CFU} / \mathrm{ml}$ and there was no significant difference $(p>0.05)$ between the treatment of sucrose concentration. After the average freeze- drying process the 
total LAB decreased by 1 log cycle, with a total between $2.75 \times 108-9.28 \times 108 \mathrm{CFU} / \mathrm{ml}$ and there was a significant difference $(\mathrm{p}<0.05)$ between the treatment of sucrose concentration

Total LAB in sucrose treatment as a cryoprotectant $5 \%$ showed significantly different numbers among other treatments. The decrease in total BAL at 5\% sucrose concentration before and after freeze-drying shows the smallest number, not up to $1 \mathrm{log}$ cycle. This is suspected, sucrose as cryoprotectant has the ability to protect the structure and function of proteins in microbial cells [5] In addition sucrose functions to strengthen cell resistance to freezing conditions. The mechanism of cryoprotectant action in cell preservation reactions is 1). The decrease in freezing point of cryoprotectant medium, 2) protection of cell membranes, 3) suppress the rate of an influence of increasing concentration [11].

The Concentration of sucrose that is too high $(7.5 \%)$ can cause osmotic imbalances both inside and outside the cell. This condition can stimulate bacterial lysis and cause bacterial death. So that in Table 1, the total LAB is lower than the $5 \%$ sucrose concentration.

\section{CONCLUSION}

Sucrose concentration significantly affected the reduced sugar content, the total viability of Lactic Acid Bacteria (LAB) after freeze-drying, but no significant effect on moisture content and total viability of BAL before freeze drying. The best treatment showed that sinbiotic yogurt with $5 \%$ sucrose concentration as a cryoprotectant. The treatment has the following characteristics: $7.51 \%$ water content, reducing sugar $14.59 \%$, the total viability of Lactic Acid Bacteria (LAB) $1.98 \times 10^{9} \mathrm{CFU} / \mathrm{ml}$ before freeze drying, and total viability of $\mathrm{LAB} 9.28 \times 10^{8} \mathrm{CFU} / \mathrm{ml}$ after freeze drying

\section{ACKNOWLEDGMENT}

The author would like to thank the Directorate of Research and Community Service Ministry of Technology and Higher Education who have funded the research through the National Strategic Research Fund, 2018.

\section{REFERENCES}

[1]. Tari, A. I N. Catur Budi Handayani dan Ali Mursyid Wahyu Muyono. "Bakteri Probiotik terhadap Mutu Yogurt Ekstrak Ubi Jalar Ungu dan Pemanfaatannya sebagai Pencegah Diare dan Imunomodulator", Laporan Penelitian Hibah Bersaing, Universitas Veteran Bangun Nusantara Sukoharjo, 2013

[2]. Speer, E.."Milk and Dairy Product Technology", CRC Press, Boca Raton London New York, 1998

[3]. Davidson, R. H. S., E. Duncan, C.R. Hackney, W.N. Ergel and J.W Boling,"Probiotic Culture Survival an Implication in Fermented Frozen Yogurt Characteristic", J. Dairy Sci. 83 : 666-676. 1999.

[4]. Chattopadhyay, M. K., "Bacterial Cryoprotectant. General Article Resonance". http:// www.Resonance.com. 2002

[5]. C. A. Morgan, N. Herman, P.A. White and G. Vosey, "Preservation of Microorganisms by Drying : A. Review. Journal of Microbiological Methods.", Vol 66. Issue 2, August 2006. 183-193. 2006.

[6]. Steel RGD, Torrie J.H, "Principles and Procedures of Statistic : A Biometrical Approach. $2^{\text {nd }}$ edition", New York : McGraw Hill Book Co, 1995

[7]. P. Bordat, A. Lerbret, J. P. Demaret, F. Affouard and M. Descamps, "Comparative Study of Trehalose, Sucrose, Sucrose and Maltose in Water Solutions by Molecular Modeling", EDP Science, 2004.

[8]. Girindra, S.E., "Dasar-dasar Biokimia", PT. Gramedia Pustaka Utama, Jakarta, 1993

[9]. Salminen, S and A.V. Wright. "Lactic Acid Bacteria : Microbiology and Functional Aspects", Marcel Dekker Inc., New York, 1998.

[10].Carvalho, A.S., J. Silva, P.H.P Teixiera. F.X Malcata, P. Gibb. Protective effect of sorbitol and monosodium glutamate during storage of freeze-dried lactic acid bacteria. Jurnal of INRA, EPD Sciences. 2003.

[11].Prihatini, F. Peranan Cryoprotectant Ekstraseluler dalam Pengencer Susu Skim terhadap Kualitas Semen Kambing setelah Pembekuan. Universitas Brawijaya. Malang. 2004. 